POLSKA AKADEMIA NAUK - ZAKEAD BADANIA SSAKOW
A $\quad$ C $\quad$ T $A$
T H E R I O L O
G
VOL. VI, 9.
BIA£OWIEŻA
20.X.1962.

Roman ANDRZEJEWSKI* \& Henryka WROCŁAWEK

\title{
Settling by Small Rodents a Terrain in which Catching out Had Been Periormed
}

\section{Zasiedlanie terenu odłowionego przez gryzonie}

[Witg 4 Figs \& 9 Tables]

I. Introduction

II. Method of investigation

III. Course of experiments .

IV. Analysis of results .

V. Discussion of results

VI. Conclusions

References

Streszczenie

\section{INTRODUCTION}

The aim of this work is an endeavour to determine the manner in which a population of small rodents liquidates the gap caused by catching out the animals on a given area.

The breach in the populations was induced experimentally by catching out the animals as accurately as possible $(75 \%-95 \%)$ from a determined area and then the course of supplementation of the terrain of capture was observed.

The experiments were carried out in forests near the Terrain Station of the Institute of Ecology of the Polish Academy of Sciences in Dziekanów Leśny.

The experimental areas were situated in a terrain more or less environmentally uniform. Two opposite longer borders of the experimental terrains are more damp than the centre. The forest growing on the experimental areas forms a PinetoQuercetum association passing into a Cariceti elongate-Alnetum on both damper borders.

The age of the pines growing on the area was of about 50 years. Their growth and undergrowth was rather abundant.

*) Present address: Polish Academy of Sciences, Mammals Research Institute at Białowieża, woj. Białystok, Poland. 


\section{METHOD OF INVESTIGATION}

For observing alterations in density of population, incoming and settling of rodents in the investigated terrain, the method described by Andrzejewski \& Pielows k i (1956) was used.

According to this method, the animals were attracted to determined places by placing in the terrain, in a chequer disposition, stands with a bait, every $13-15 \mathrm{~m}$.

In these stands the animals were then caught alive in traps and individually marked by toe-clipping. They were then released at the place of capture.

Results of capturing and recapturing were listed after a "calendar of catches" (Petrusewicz \& Andrzejewski, 1962) and the following data were calculated:

1. number of animals caught on the area:

a. number of recaptures,

b. number of captures of new animals (caught for the first time)

2. length of sojourn of single individuals on the investigated area

3. distribution of the animals.

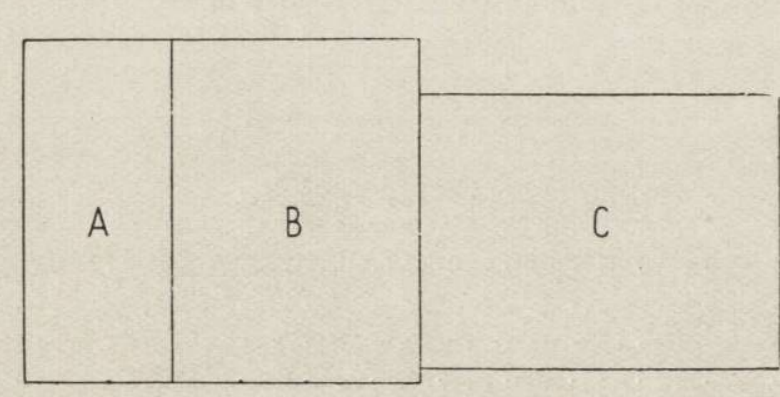

a.

Fig. 1, a) Scheme of experiment $1-7$ area. A - control area, B - experimental area, before increase. A+B - experimental area, C - control area, after increase.

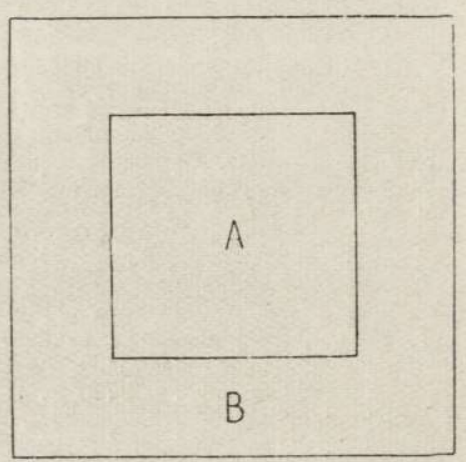

b.

Fig. 1, b) Scheme of experiment 8 area.

A - experimental area,

B - control area.

The method applied for capturing and listing permits:

1. a rather accurate information as to numerousness and composition of populations of separate species

2. knowledge of the life history of every individual living in the investigated area

3. catching out of about $90-95 \%$ of mice living on the investigated area.

8 experiments were carried out in the following manner: there were stands for attracting and capturing of mice - an experimental one, on which capturing was carried out, and a control area, bordering with the experimental one, for comparison of processes taking place under the influence of experiments and in their immediate environment (Fig. 1). The ninth and last experiment had no control area.

The scheme of experiments was the same for all of them and was divided into 3 stages (Fig. 2). 
Stage I - the numerical composition and disposition of animals on the investigated area was determined. Stage II - capturing of all animals found on the experimental area which were then taken away. Stage III - observation of the process of filling up of the produced gap, that is incoming and settling of new mice.

In experiments $1-7$ traps were placed during two consecutive days and nights in a week: on the first day on rows with an unpaired numeration, on the following one - on those with paired numbers. Mice were taken out from the traps twice in 24 hours - on 22 o'clock and 8-10 o'clock.

After three weeks of capturing on the entire investigated area, catching out of animals was carried out on six consecutive nights on the experimental area (Fig. 2). In this period traps were placed three times on each stand of the area.

At the time of capture on the control area a normal registration of mice was carried out during two days. The period between the two captures was of about 6 weeks, and then the animals were only marked and released (Fig. 2). The date of separate experiments and the number of rows and points on the experimental and control areas are presented in Table 1. For the fourth experiment the experimental

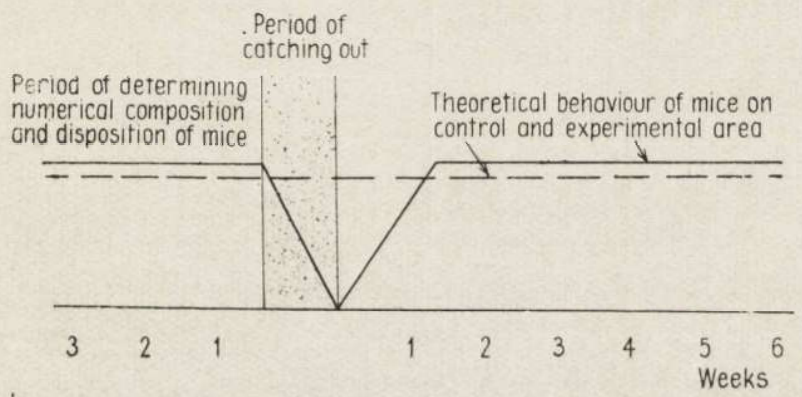

Fig. 2. Scheme of experiment.

area was changed into a control one and inversely (Fig. 1). After a year of experimenting, the area was increased by uniting the two areas into a single one, while a new control area, being a prolongation of the previous one, was arranged. Experiments $5-7$ were conducted on the augmented area.

In experiment 8 the experimental area was surrounded by the control one (Fig. 1). Capturing took place daily, simultaneously on both areas, while in separate points the trap remained for 24 hours and was replaced, for the next 24 hours, by a platelet containing the bait. After 20 days of assessing the numerical composition and disposition of the rodents, capturing was carried out during 13 days on the experimental area. During the following 20 days after catching, a normal listing of mice according to the system used before catching was carried out.

In experiment 9 the experimental area was prepared. Capture of rodents was conducted daily in all points (mice were not attracted) for 37 days and then for 14 consecutive days catching out of the animals was carried out. Directly after the capture, registration of caught rodents was conducted during 3 days and then a 4th registration at intervals of one week, during which the traps remained for only two days of the week in all the points.

A comparison of the number of mice settled before the catching out and caught during ...rmation of the gap (Table 2) demonstrated that the method employed is sufficient for capturing most of the mice living there. In separate experiments during 
the six days of capturing $75-97 \%$ of previously marked individuals, considered as settled, were caught (Tables 2 and 3 ).

Independently of the decrease in the number of mice caused by capturing, the number of individuals diminishes in a natural manner. For instance in the first experiment out of 38 mice of the permanent settlement 33 were caught, 2 remained on the area and 3 mice were found missing during catching out (Table 2).

Table 1.

Experimental periods and size of experimental areas.

\begin{tabular}{|c|c|c|c|c|c|c|c|}
\hline \multirow[b]{2}{*}{$\begin{array}{l}\text { Exp. } \\
\text { no. }\end{array}$} & \multirow[b]{2}{*}{ Data } & \multicolumn{3}{|c|}{ Exper1mental area } & \multicolumn{3}{|c|}{ Control area } \\
\hline & & $\begin{array}{l}\text { Number } \\
\text { of rows }\end{array}$ & $\begin{array}{l}\text { Number of } \\
\text { points } 1 \text { n } \\
\text { row }\end{array}$ & $\begin{array}{l}\text { Polnts } \\
\text { total }\end{array}$ & $\begin{array}{l}\text { Number } \\
\text { of rows }\end{array}$ & $\begin{array}{l}\text { Number of } \\
\text { points in } \\
\text { row }\end{array}$ & $\begin{array}{l}\text { Points } \\
\text { total }\end{array}$ \\
\hline 1 & 3. XI. $56-13$. I. 57 & 10 & 14 & 140 & 6 & 14 & 84 \\
\hline 2 & $1.57-25.111 .57$ & 10 & 14 & 140 & 6 & 14 & 84 \\
\hline 3 & 26. II. $57-13$. v. 57 & 10 & 14 & 140 & 6 & 14 & 84 \\
\hline 4 & 28. IV. $57-23$. VI. 57 & 10 & 14 & 140 & 6 & 14 & 84 \\
\hline b & 1. VII. $57-12$. IX. 57 & 16 & 14 & 224 & 14 & 11 & 154 \\
\hline 6 & 28.VIII.57 - 7. XI. 57 & 16 & 14 & 224 & 14 & 11 & 154 \\
\hline 7 & 6. XI. $58-16$. I. 58 & 16 & 14 & 224 & 14 & 11 & 154 \\
\hline 8 & 30. IX . $60-21$. XI. 60 & 10 & 10 & 100 & & & 224 \\
\hline 9 & 15. IX. $59-4 . X I I .59$ & 15 & 14 & 210 & - & - & - \\
\hline
\end{tabular}

\section{Table 2.}

Catching out intensity in separate experiments.

(A part of settled mice declines during trapping, independently of the experiment).

\begin{tabular}{|c|c|c|c|c|c|}
\hline $\begin{array}{l}\text { Exp. } \\
\text { no. }\end{array}$ & $\begin{array}{l}\text { Number of m1ce } \\
\text { settlee before } \\
\text { catching out }\end{array}$ & $\begin{array}{l}\text { Number } \\
\text { of caught } \\
\text { settled m1ce }\end{array}$ & $\begin{array}{l}\text { Number } \\
\text { of not caught } \\
\text { settled m1ce }\end{array}$ & $\begin{array}{l}\text { \% of not } \\
\text { caught } \\
\text { settled m1ce }\end{array}$ & Intens1ty $\%$ \\
\hline 1 & 38 & 33 & 2 & 5 & 95 \\
2 & 5 & 4 & 1 & 20 & 80 \\
3 & 8 & 5 & 2 & 25 & 75 \\
4 & 12 & 10 & 1 & 8 & 92 \\
5 & 28 & 17 & 4 & 14 & 86 \\
6 & 27 & 23 & 3 & 11 & 89 \\
\hline 7 & 31 & 25 & 1 & 9 & 97 \\
\hline Avg. & 21.3 & 16.9 & 2 & 8 & 90.7 \\
\hline 8 & 12 & $181^{\circ}$ & 1 & 0 & $1 c 0$ \\
\hline 9 & 228 & & 0 & & 92 \\
\hline
\end{tabular}

The captured animals were divided into the following groups:

1. permanent settlement. In experiments $1-7$ mice that were being captured during two weeks at least - in experiments 8 and 9 mice captured at least three times, at intervals not longer than 10 days. The criterion for evaluating settlement was determined on the base of analysis of time intervals between capturing, taking in consideration the mean period of time during which the probability of not capturing an animal amounts to 1.0 (A n drzejewski, in litt.). 
2. Incoming mice, caught for the first time, immigrants and animals born on the area:

a. settling, incoming specimens captured more than once (as in the permanent settling).

b. migrating, incoming specimens, caught only once and never more.

In the period of trapping and afterwards, analysis of the origin of mice incoming to the area on which capture had been carried out allows to state eventual transfer of settled mice from the control area to the experimental one or inversely.

Behaviour of the population on the basis of the behaviour of single individuals. was analysed in separate experiments.

The size of the material on which the present work is based, is presented in Table 4.

Table 3.

Number of settled mice caught on separate days of catching out (experiment 9).

\begin{tabular}{|l|c|r|r|r|r|r|r|}
\hline \multirow{2}{*}{ Species } & Uumber of settled mice & \multicolumn{4}{|c|}{ Days of catching out } \\
& a neek before catch1ng out & 1 & 2 & 3 & 4 & 5 & 6 \\
\hline C. glareolus & 5 & 0 & 1 & 1 & 1 & 1 & 1 \\
A. acrar1us & 140 & 69 & 32 & 10 & 8 & 7 & 7 \\
A. flavicoli1s & 34 & 13 & 12 & 2 & 2 & 2 & 3 \\
\hline Total & 179 & 82 & 45 & 13 & 11 & 9 & 10 \\
D of caught & & 45.7 & 70 & 78 & 84 & 89 & 95 \\
\hline
\end{tabular}

Table 4.

Number of capturing, captures and individuals caught.

\begin{tabular}{|c|c|c|c|c|c|c|}
\hline $\begin{array}{l}\text { Experiment } \\
\text { Area size } \\
\text { Observation number: }\end{array}$ & \multicolumn{2}{|c|}{$\begin{array}{c}1-7 \\
8.6 \text { ha } \\
58 \text { week:1y }\end{array}$} & \multicolumn{2}{|c|}{$\begin{array}{c}8 \\
7.3 \text { ha } \\
53 \text { da1ly }\end{array}$} & \multicolumn{2}{|c|}{$\begin{array}{c}9 \\
4.7 \text { ha } \\
54 \text { dally } \\
4 \text { weekly }\end{array}$} \\
\hline Number & Ind1v1dues & Captures & Ind1v1dues & Captures & Ind1 v1dues 3 & Captures \\
\hline Apodemus agrarius & 643 & 1177 & 62 & 251 & 339 & 3143 \\
\hline Clethrlonomys glareolus & 546 & 1240 & 108 & 122 & 113 & 376 \\
\hline Apodemus elavicoll1s & 128 & 276 & 54 & 116 & 104 & 710 \\
\hline Total & 1317 & 2633 & 224 & 489 & 556 & 4229 \\
\hline
\end{tabular}

\section{COURSE OF EXPERIMENTS}

Three species of rodents appeared on the experimental terrain: Apodemus agrarius ( $\mathrm{Pall}$ a s 1771), A. flavicollis (M e l ch i or 1834) and Clethrionomys glareolus ( $\mathrm{S} \mathrm{hr}$ e b e r 1780). When analysing material, both from catching out as from "regeneration" processes of the gap in populations, all three species were treated in common - with the exception of calculation of the mean time of the presence of mice on the investigated area.

The quantitative level of population processes taking place on experimental areas, as well as their course, depend in a certain measure on the 
general numerical state of mice. Rather fundamental differences shall be occasioned by the season in which the experiment is conducted ( $\mathrm{N}$ a umov, 1948; 1955).

The primeval forest of Kampinos, to which belong the forests in which our investigations were conducted, is characterised by a specific course of dynamics in the numerousness of rodents. In the year cycle of nume-
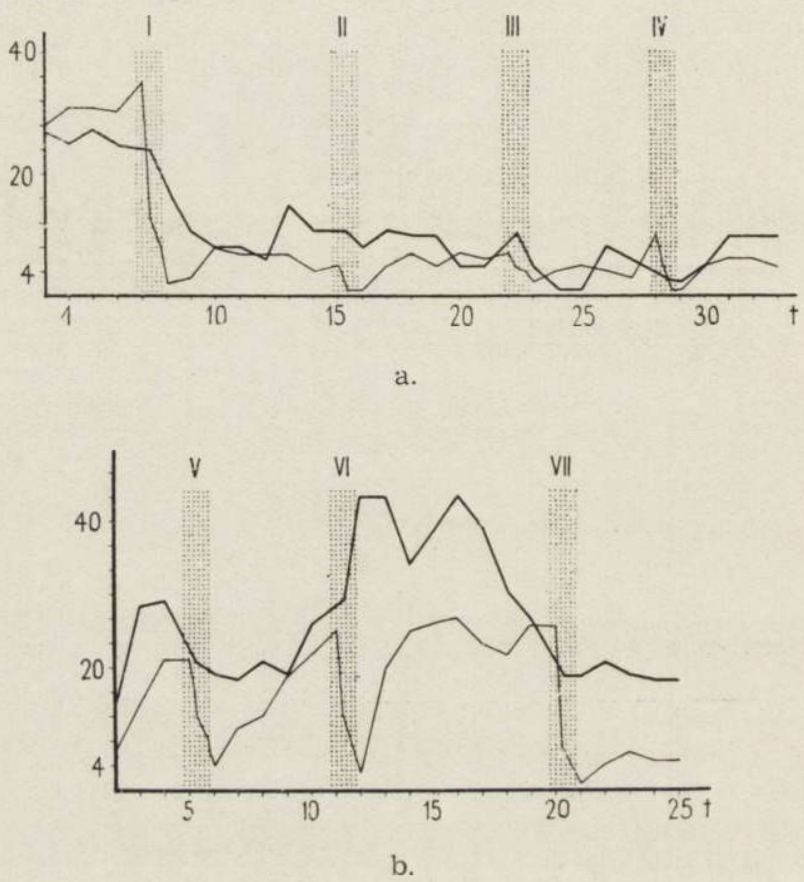

Fig. 3. ( $\mathrm{a}$ and $\mathrm{b}$ ) Changes in number of resident mice in experiments $1-7$. Dotted - trapping periods, Roman numeral - experiment No. experimental area, control area.

rical dynamics there are two fundamental peaks: the autumn peak (October) resulting from the summer reproduction period and the spring one (March), more weakly expressed, connected with early spring thaws and the immigration of rodents from the parts of the primeval forest flooded by ground water. In April and May the spring minimum of rodents appears (Andrzejewski, in litt.).

Our experiments took place at different moments of these numerical dynamics.

Experime $\mathrm{t}$ 1. This experiment begins in the period of a decrease in the amount of mice, after the autumn numerical peak. 
The process of diminution of the number of animals belonging to the permanent settlement can be observed on the control area (Fig. 3) ${ }^{1}$ ).

At the same time decrease of the number of mice on the experimental area is considerably accelerated and magnified through catching out. After capture an increase in the number of mice takes place, a renovation of the population.

This increase attains however a rather low level in comparison with the period before the capture $-30.7-6$ (Fig. 3a) ${ }^{2}$ ).
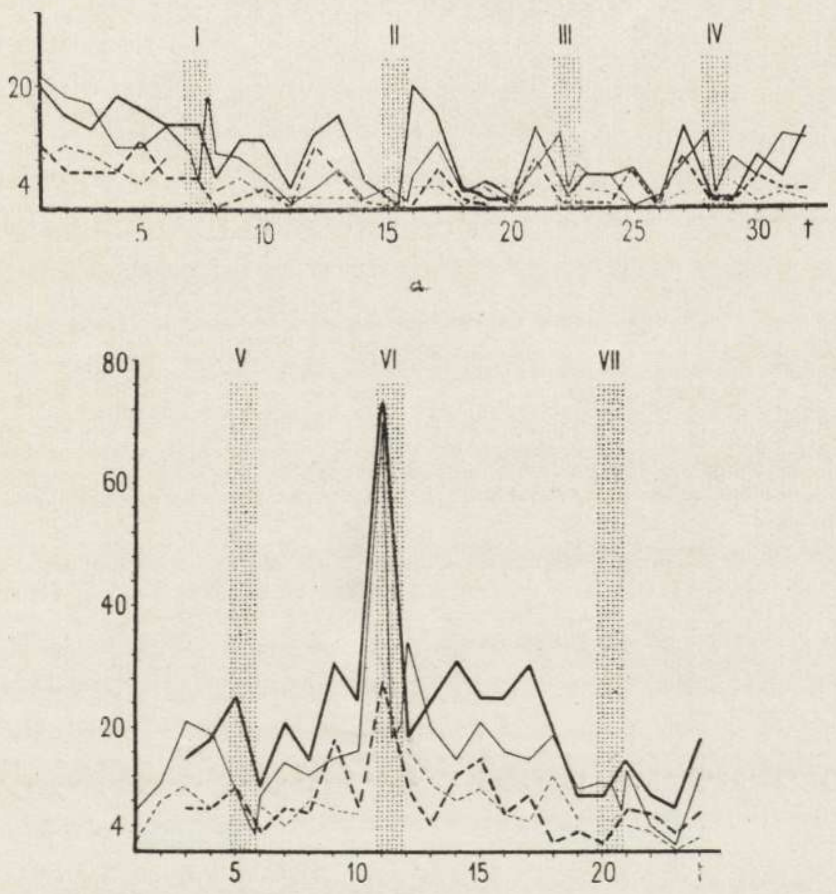

b.

Fig. 4 ( $\mathrm{a}$ and $\mathrm{b}$ ). Changes in number of invaiding (constant line) and settling mice (dotted line) in experiments $1-7$.

experimental area, control area.

Incoming before the capture is firstly more or less equal on both areas $(11-15)$ (Fig. 4a). In the second week before the capture incoming diminishes on the experimental area and increases on the control one. In the next week, however, an equalisation of both curves depicting incoming takes places on both areas. After capture the incoming on the experi-

1) Numerical data of capture reduced to a comon dimmension of both areas.

2) The numbers presented here will characterise the mean figures for three weeks before or three weeks after the capture - or for the experimental and control areas. 
mental area increases, considerably surpassing in the first week incoming in the control area and falling later below its level (9-7.3) (Fig. 4a).

Settlement. Fluctuations in the number of mice belonging to the settling group are rather big on both areas before capture.

After the capture, settling on the experimental area surpasses the settling on the control one $(3.3-1.3)$, which then descends to a rather low level. In the third and fourth week an equalisation of the curves for settlement takes place on both areas.

Experiment 2. This experiment was carried out in the winter of $1956 / 57$, in a period of snow conditions exceptionally favourable for small rodents. Pericds of more intensive frosts were relatively short. All this created favourable conditions for the survival of mice. The number of mice on the control area increases slightly during the whole period of the experiment. Capture causes a strong reduction in the number of mice on the experimental area. Regeneration of the population rapidly attains nearly the same level as that before the capture (6-6) (Fig. 3a).

Incoming. On the control area, during a period of three weeks before and two weeks after the capture, an increased incoming can be observed, with the exception of the period of catching out in which the number of incoming animals greatly decreases. On the experimental area incoming surpasses initially the level of before the capture $(3.3-6)$, but already in the third week the incoming curves for both areas attain nearly the same level (Fig. 4a).

Settlement on the experimental area surpasses, in the first week after capture, the settlement on the control area. Later, fluctuations in the amount of mice settling on both areas correspond to the fluctuations of the curves for incoming (Fig. 3a).

Experiment 3 . The number of mice regularly settled does not differ essentially from the number in the preceding period. The number of mice belonging to this group on the control area surpasses slightly the level of the experimental one (6-7). After the period of capture a decrease in the amount of permanently settled mice on the control area is observed, followed by a return to the previous level (Fig. 3a). The general number of mice in this period is, on the whole, very low.

Incoming. After capture and release it is maintained on both areas on approximately the same level.

Settlement. Directly after capture it is greater on the experimental area, being equal to zero on the control one. In the third week after capture settling on the control area exceded that on the experimental one, which had been reduced to zero at that time (Fig. 4a).

Experiment 4 . The experiment was carried out when the experi- 
mental area had been converted into a control one and inversely. The permanently settled part of population on the control area surpasses before and after the capture the numerical level of the experimental area $(4-5.3)$. After a period of regeneration the number of mice permanently resident on the experimental area surpasses the level before catching out $(4-6)$ (Fig. 3a). The fundamental course of the regeneration of the population does not differ from the preceding ones.

The incoming on the experimental area after catching out transgresses at first the level of the control area $(8.3-5)$ later the difference between the curves diminishes.

Settling. Immediately before capture on the control area it surpasses the settling on the experimental area $(0.7-5)$. After capture the levels of both curves do not differ essentially from each other (2.3-3) (Fig. 4a).

As already mentioned when describing the method, captures 5, 6 and 7 were carried out on the enlarged area.

Establishing of two identical areas in the terrain is not possible, especially because of the mosaic-like structure of the evironment (B orowski \& Dehnel, 1952). However the course of both areas along a natural environmental zone might indicate their similarity. They were therefore treated in common in the description of the terrain. It appeared, though, that the new control area was distinctly characterised by a higher level in the number of mice.

The presence of a larger quantity of mice on the control area was the cause that the level of fluctuations of the number of incoming and settling animals was higher than on the experimental area (Fig. 3b, 4b).

Experiment 5. Beginning of the increase in the number of mice in the terrain. After catching out, a rapid "regeneration" of the population, and a small decrease of mice, takes place on the experimental area.

Incoming after catching out increases rapidly on both areas; this is caused by an increase of the general number of animals. Settling attains a rather high level on both areas.

$\mathrm{Experiment} 6$. The period of catching out takes place in a moment of considerable incoming on both areas. On the control area an especially rapid increase in the number of mice belonging to the resident population can be observed. On the experimental area a rapid "regeneration" of this population takes place, and the number of mice surpasses the level before catching out (18-24).

Incoming is rather great on both areas of capture ( 72 mice on the control area, 108 on the experimental one). After trapping incoming is still high on both areas, in spite of the fact that a very great number of mice have been caught (191) (23.5-25.3). 
Settling after capture increases at first on the experimental area in comparison with the period preceding it (7-12). At a later period settling diminishes. Settling decreases on the control area after catching out. It then runs along more or less on the same level as that of the experimental area (Fig. 3b).

The phenomenon of such a great incoming as in the case of the above experiment was exceptional and greatly deformed the general picture of its course.

Experiment 7 . The period of the decrease of the number of mice in the terrain. On the control area the number of permanent settled mice diminishes already before catching out.

The catching out itself, however, reduces rapidly the number of mice in the experimental area.

The "regenerative" process of the population has a relatively slow course and the small number of mice does not attain the level before catching out ( $24-5)$.

Incoming. The general level of the incoming also decreases, although a certain increase and some fluctuations in the number of mice on both areas can be noticed (Fig. $3 \mathrm{~b}$ ).

Settling on the control area after catching out is slightly higher from that on the experimental one $(2.3-6)$. The course of both curves is similar (Fig. 3b).

Experiment 8. This experiment was carried out in 1960 , in conditions of a considerable lowering of the number of rodents. After an intensive catching out which reduced by $95 \%$ the permanent settlement of the experimental area, the liquidation of the gap thus formed in the population progresses slowly, owing to a small incoming of new mice. During the trapping and 20 days after, 24 individuals came into the experimental area, of which 17 were caught during capture and of the remaining 7.5 settled on the area. 39 individuals came onto the control area of which 19 settled.

Experiment 9 . The experiment was carried out in 1959 at a period when Apodemus agrarius appeared in mass numbers. The general number of this species attains a very high level, tenfold higher than that of 1958 . Catching out was conducted at the period of a natural and rapid reduction of this mass appearance and greatly hastened the course of this phenomenon on the area in question. After catching out regeneration was very slight and mostly Clethrionomys glareolus came onto the area.

A similar invasion of this species was also observed on other experimental areas and it might be that it was related to the general reduction of A. agrarius (Andrzejewski \& Wrocławek, 1961). 


\section{ANALYSIS OF RESULTS}

In all experiments catching out was effective and caused a considerable reduction of the resident population (Table 2). The numerousness of the population recovers the level existing before catching out in the $2-4$ week.

After catching out on the control area a more or less considerable

Table 5.

Number of settled mice on control area, passing after trapping onto the experimental area.

\begin{tabular}{|l|r|r|r|r|r|r|r|r|r|}
\hline Experiment No. & 1 & 2 & 3 & 4 & 5 & 6 & 7 & 8 & Total \\
\hline Number of m1ce settled: & & & & & & & & & \\
On control area a week before capture & 25 & 11.5 & 5 & 1.5 & 31 & 27 & 28 & 38 & 167 \\
On the experimental area $\left\{\begin{array}{l}\text { caught } \\
\text { settled }\end{array}\right.$ & 2 & 1 & 1 & 0 & 3 & 2 & 0 & 0 & 9 \\
\hline
\end{tabular}

Table 6.

Number of mice: resident, incoming and settling (experiments $1-7$ ).

\begin{tabular}{|c|c|c|c|c|c|c|c|c|c|c|c|}
\hline \multirow{3}{*}{$\begin{array}{l}\text { Exp. } \\
\text { no. }\end{array}$} & & \multicolumn{5}{|c|}{ Experimental area } & \multicolumn{5}{|c|}{ Control area } \\
\hline & & \multirow{2}{*}{$\begin{array}{l}\text { Avg. } 3 \text { weeks } \\
\text { before capture }\end{array}$} & \multicolumn{4}{|c|}{ ireek aPter capture } & \multirow{2}{*}{$\begin{array}{l}\text { Avg. } 3 \text { weeks } \\
\text { before capture }\end{array}$} & \multicolumn{4}{|c|}{ Week after capture } \\
\hline & & & 1 & 22 & 3 & 4 & & 1 & 2 & 3 & 4 \\
\hline \multirow{8}{*}{ 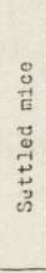 } & 1 & 30.7 & 2 & 3 & 8 & 7 & 26 & 18 & 11.5 & 8 & 8 \\
\hline & 2 & 6 & 1 & 5 & 7 & , & 11 & 8 & 11.5 & 10 & 10 \\
\hline & 3 & 6 & 2 & 4 & 5 & 4 & 7 & 5 & 1.5 & 1.5 & 8 \\
\hline & 4 & - 4 & 1 & 5 & 6 & 6 & 5.3 & 3 & 5 & 10 & 10 \\
\hline & 5 & 13.7 & 4 & 10 & 12 & 19 & 25.5 & 19.5 & 18 & 21 & 19.5 \\
\hline & 6 & 18 & 3 & 20 & 26 & 27 & 22.5 & 48 & 48 & 37 & 45.5 \\
\hline & 7 & 24 & 1 & 4 & 6 & 5 & 35 & 19.5 & 21 & 19.5 & 18 \\
\hline & $\bar{x}$ & & 2 & 7.3 & 10 & 10.4 & & 17.3 & 16.6 & 15.3 & 16.7 \\
\hline \multirow{8}{*}{ 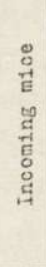 } & 1 & 11 & 9 & 8 & 5 & 1 & 15.5 & 5 & 11.5 & 11.5 & 3 \\
\hline & 2 & 3.3 & 5 & 10 & 2 & 4 & 10.5 & 20 & 15 & 3 & 1.5 \\
\hline & 3 & 4 & 5 & 5 & 0 & 1 & 5 & 5 & 5 & 6.5 & 0 \\
\hline & 4 & 3 & 8 & 5 & 12 & 11 & 6.3 & 1.5 & 8 & 8 & 13 \\
\hline & 5 & 17 & 9 & 14 & 12 & 15 & 22 & 10.5 & 21 & 15 & 31.5 \\
\hline & 6 & 14 & 34 & 20 & 15 & 21 & 23 & 19.5 & 25.5 & 31.5 & 25.5 \\
\hline & 7 & 15 & 13 & 4 & 1 & 13 & 17 & 15 & 9 & 7.5 & 18 \\
\hline & $\bar{x}$ & & 12 & 9.4 & 6.9 & 9.4 & & 10.9 & 13.5 & 11 & 13 \\
\hline \multirow{8}{*}{ 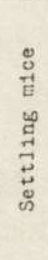 } & 1 & 6 & 3 & 5 & 2 & 1 & 7.6 & 0 & 1.5 & 3 & 0 \\
\hline & 2 & 1 & 4 & 4 & 0 & 3 & 4 & 0 & 6.5 & 1.5 & 0 \\
\hline & 3 & 2 & 3 & 2 & 0 & 0 & 2.6 & 0 & 0 & 6.5 & 0 \\
\hline & 4 & 0.7 & 4 & 1 & 2 & 1 & 5 & 1.5 & 5 & 3 & 3 \\
\hline & 5 & 8 & 7 & 4 & 8 & 7 & 11.5 & 3 & 7.5 & 6 & 18 \\
\hline & 6 & 7 & 17 & 11 & 8 & 10 & 10.5 & 10.5 & 4.5 & 12 & 15 \\
\hline & 7 & 7.3 & 4 & 3 & 0 & 2 & 4.5 & 7.5 & 6 & 3 & 6 \\
\hline & $\bar{x}$ & & 6 & 4.3 & 2.9 & 3.4 & & 3 & 4.4 & 5 & 6 \\
\hline
\end{tabular}


decrease of the number of settled mice takes place, which later becomes equal to the previous numerical level. Analysis of the displacement of mice between the control and experimental areas demonstrated that the number of animals passing from the control area to the experimental one is insignificant (Table 5). It might be possible that the influence of catching out in the experimental area upon the control area consists in a heightening of migration, which in turn causes a temporary decrease in the number of mice on the control area.

In experiments $1-7$ accurate numbers of mice from the permanent settling of the incoming ones and of those that had settled were listed three weeks before and four weeks after catching out, with the aim of obtaining general rules for the regenerative processes (Table 6.).

Then settlement and incoming processes were compared and the number of mice of resident population on both areas before and after trapping and the comparison of the control and experimental areas was carried out in the following manner:

1. Mean number of mice (for ex. of incoming ones) during three weeks before trapping on the experimental area with numerical results for each of the four weeks after capture on the experimental area.

2. Mean number of mice 3 weeks before trapping on the control area, with numerical results for each of the four weeks after catching out - on the control area.

3. Mean number for 4 weeks before trapping on the control area, with numerical results for each of the 3 weeks before catching out on the experimental area.

4. Mean number for 4 weeks after trapping - on the control area, with numerical results for each of the 4 weeks after capture - on the experimental area.

If trapping has an actual influence on processes of decreasing, settling, incoming and on the number of resident mice, differences in their course before and after trapping on the experimental area ought to be much greater than the corresponding differences in the same period on the control area. When comparing the control and experimental area before catching out the differences should be insignificant, while difference between the area where capture took place and the control one ought to be considerable and significant.

Mean numbers obtained for both areas were compared by means of $\mathrm{S} t \mathrm{ud}$ e $\mathrm{n}$ t's $t$ test. Comparing the two dependent courses of observation, differences between the mean number of rodents before capture and the mean results for separate weeks after trapping, or between the mean numbers for the control and the experimental area are calculated. Tables 
Table 7.

Probability of insignificance of difference between mean figures three weeks before trapping (marked "O") and numerical results for each of the weeks after trapping.

\begin{tabular}{|l|c|c|c|c|}
\hline Week & $0 / 1$ & $0 / 2$ & $0 / 3$ & $0 / 4$ \\
\hline \multicolumn{5}{|c|}{ Exrer1mental area } \\
\hline Constani settlement & 0.000 & 0.066 & 0.287 & 0.462 \\
Settling & 0.230 & 0.425 & 0.058 & 0.319 \\
Incoring & 0.205 & 0.425 & 0.230 & 0.425 \\
\hline \multicolumn{5}{|c|}{ Control area } \\
\hline Constant settlement & 0.258 & 0.287 & 0.319 & 0.287 \\
Settling & 0.182 & 0.353 & 0.500 & 0.425 \\
Incoming & 0.500 & 0.319 & 0.075 & 0.319 \\
\hline
\end{tabular}

Table 8.

Probability of insignificance of difference between the experimental and control area.

\begin{tabular}{|l|c|c|c||c|c|c|c|}
\hline & \multicolumn{3}{|c|}{ Feek before catching out } & \multicolumn{5}{|c|}{ Week after catching out } \\
& 3 & 2 & 1 & 1 & 2 & 3 & 4 \\
\hline Constant settletsent & 0.205 & 0.50 & 0.287 & 0.002 & 0.008 & 0.031 & 0.019 \\
Settling & 0.287 & 0.425 & 0.258 & 0.142 & 0.161 & 0.040 & 0.258 \\
Inconing & 0.005 & 0.031 & 0.205 & 0.267 & 0.051 & 0.097 & 0.161 \\
\hline
\end{tabular}

Table 9.

Mean time of presence of mice on investigated area.

A. agrarius $t_{\mathrm{e}}=11, \mathrm{t}=2.66$

C. glareolus $\mathrm{t}_{\mathrm{e}}=3.4, \mathrm{e}=0.01 ; \mathrm{t}=2.548$.

\begin{tabular}{|c|c|c|c|c|c|}
\hline \multirow{2}{*}{ 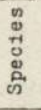 } & \multirow[b]{2}{*}{$\begin{array}{c}\text { Experiment } \\
\text { No. }\end{array}$} & \multicolumn{2}{|c|}{ Exper1mental area } & \multicolumn{2}{|c|}{ Control area } \\
\hline & & $\begin{array}{c}\text { No. } \\
\text { Ind1v1duules }\end{array}$ & $\begin{array}{l}\text { Mean time } \\
\text { of presence }\end{array}$ & $\begin{array}{c}\text { No. } \\
\text { Individuales }\end{array}$ & $\begin{array}{l}\text { Mean t1me } \\
\text { of presence }\end{array}$ \\
\hline \multirow{8}{*}{ 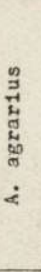 } & 1 & 2 & 2.5 & 2 & 1.5 \\
\hline & 2 & 5 & 2.6 & 4 & 3 \\
\hline & 3 & - & - & - & - \\
\hline & 4 & 3 & 4 & - & - \\
\hline & 5 & 12 & 3.4 & 5 & 1.4 \\
\hline & 6 & 22 & 3 & 2 & 2 \\
\hline & 7 & - & - & - & - \\
\hline & & & $\bar{x}=3.1$ & & $\bar{x}=2$ \\
\hline \multirow{8}{*}{ 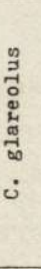 } & 1 & 8 & 3.3 & - & - \\
\hline & 2 & 3 & 3.3 & 1 & 3 \\
\hline & 3 & 5 & 3.2 & 1 & 2 \\
\hline & 4 & 6 & 3.5 & 5 & 1.8 \\
\hline & 5 & 6 & 3.5 & 5 & 1.6 \\
\hline & $\begin{array}{l}6 \\
7\end{array}$ & 19 & 3.3 & 9 & 3 \\
\hline & 1 & 6 & 3.8 & 3 & 2 \\
\hline & & & $\bar{x}=3.4$ & & $\bar{x}=2: 5$ \\
\hline
\end{tabular}


7 and 8 demonstrate the probability that differences in mean values before and after catching, or between the experimental and control area, are statistically insignificant. The values of probability, lower than 0.05 , determining the essence of the difference, are stressed.

Comparison of the number of mice pertaining to separate groups (resident population, incoming animals, settling ones) according to the previously presented scheme, gives the following picture:

1. The number of mice settled in the first week after trapping is effectively lower in relation to the resident population before the trapping. The increase of the amount of settling or incoming mice, even if it takes place, is not statistically significant (Table 7).

2. For four weeks after trapping the number of mice settled on the experimental area is effectively lower on the control area.

3. Settling and incoming do not show essential differences (Table 8). A really lower incoming in the 3 rd week before trapping can only have an accidental origin (Table 8).

In experiments $1-7$, indexes were calculated for the time of sojourn of mice which migrated onto a area during two or three weeks after trapping had been carried out and remained there until the next capture. This was done with the aim of characterising the length of stay of animals after catching out on the experimental and control area.

The interval between trapping being of 6 to 8 weeks, groups of mice that could stay on the area in theory for $1-5$ weeks, were selected for all trappings. The actual time of sojourn of all mice of the groups was then summed up and mean values were calculated as indexes for determining the length of their stay on the area (Table 9).

As the mean length of the time of sojourn (that is the time from the first capture to the last) of individual species differs (A $n d r z$ e je w s k i \& W i e r z bowska, 1960), these indexes were calculated separately for Apodemus agrarius and for Clethrionomys glareolus. No index was established for the species Apodemus flavicollis, which appeared in small numbers. The indexes thus obtained for the experimental and control area were compared according to $\mathrm{St} u \mathrm{~d}$ e $\mathrm{n}$ t's $t$ test. It was stated that the lapse of time spent by both species on the experimental area was longer than on the control one and that the difference is significant on the 0.01 level (Table 9).

\section{DISCUSSION OF RESULTS}

In experiments $1-7$, when observing the course of the curve for the number of mice of the permanent population, a more rapid rate of regeneration can be seen in periods when the number of animals is greater 
(Exper. 2, 5, 6). At the time when the number of animals decreases the rate of regeneration is slower (Exper. 1, 7, 8, 9). It can be noticed that independently of the number of mice, the time of regeneration of the population is short (about 4 weeks). After four weeks the number of mice settled on the area attains a determined level. It can be equal to, (Exper. 2,4 ), lower (Exper. 1, 3, 7, 8, 9) or higher (Exper. 5, 6) than the level before trapping and numerical differences in separate experiments are only expressed on the level of curves. The new numerical level results from the general numerosity of the population surrounding the area on which capture had been carried out. In years with a small condensation of rodents and in the period of the spring minimum the level of regeneration is low; it is high in the autumn peaks. This result seems to corroborate the standpoint of $\mathrm{Naumov}$ (1955) that the rate of liquidation of the gap can depend on the numerical relation on the investigated terrain. The period of four weeks, admitted in calculations of "regeneration", is sufficient - after this period the influence of trapping on the course of the curve for the resident population is no longer apparent.

Calhoun \& W e b b (1953) observed a considerable incoming during the time when capturing was being carried out on two areas on which the resident part of the population had been captured previously. They explain by means of two hypotheses this movement in the direction of the "vacuum" thus formed:

I. When the surface of individual areas is limited by areas with different animals and the separate individuals usually avoid mutual contacts, then the removal of animals from one side of the area ought to cause a displacement of activity of the individuals, from the border with a considerable concentration of neighbours towards the emptied area.

II. If the animals strive to maintain a certain level in the number of their mutual meetings, an alteration of this level caused by capture of a certain number of animals shall provoke a more intensive movement on the border of the evacuated terrain, aiming at a return to the previous level of meetings.

Calhoun \& Webb affirm that a too small area for capture shall not provoke a destroying of settled animals, as the determined level of meetings can be restored by means of an increase of mobility without change of the habitual living place. Thus, in the first case, the animals occupying the terrain on which capture had been conducted, would belong, first of all, to the permanently settled group. In the case of a small area it can be expected that the migrating group shall settle on it.

We have demonstrated that animals settled on the control area, that is on the terrain directly contiguous to the experimental area or surrounding 
it, immigrate onto it in extremely small numbers (Table 5). The majority of incoming animals is therefore composed of migrating animals.

B or ow s k i \& D e h n e l (1952) achieve similar results, using cylinders for capture on defined areas.

This would prove that a certain conservatism exists in a part of the settled population in relation to its area. Regeneration of the gap would therefore take place at the cost of mice belonging to the migrating part of the population. This signifies that in our case the phenomena suggested by $\mathrm{Calhoun} \& \mathrm{We}$ b b do not take place.

These results are in accordance with those obtained by $\mathrm{H}$ a y n e (1949) for Microtus arvalis. He did not ascertain, after trapping, that the centres of activity of individuals from neighbouring fields are displaced towards the area where capture had been carried out.

Liquidation of the gap in the population can theoretically take place by means of a greater settling of incoming animals or by a diminished decrease of their numbers in comparison with the surrounding terrains. A statistical analysis of the process of incoming and settling demonstrated that, as result from the experiments, a basic means for regeneration of the population was the longer period of time during which settling individuals remained on the experimental area, as compared with the control one.

A similar result was obtained by investigating the mechanism of considerable numerical increase of A. agrarius in 1959. It was stated that the mass appearance of this species took place, among others, by means of a greatly prolongated time of sojourn of individuals on the investigated area (Andrzejewski \& Wroclawek, 1961). We could not, however, demonstrate in our experiments an increased incoming of individuals onto an area deprived of resident animals. This might confirm, once more, the fact that the level and rate of regeneration depend on conditions existing in the entire population.

\section{CONCLUSIONS}

1. The process of filling of the gap takes place at the cost of mice migrating among the surrounding population and not at the cost of mice settled on the periphery of the terrain in which trapping had been carried out, as could be inferred from the suggestion of Calhoun \& We b b (1953).

2. Regeneration takes place through increase of the time of settling of immigrants on the area where capture had been carried out. In the conditions in which these experiments have been conducted, it did not prove possible to demonstrate the increase of the number of incoming mice settling on the area where capture had been carried out, as compared with the control area on which capturing had not taken place.

3. The rate of "regeneration" of the gap in the population depends on the general state of the numerical level of the surrounding population. 


\section{REFERENCES}

1. Andrzejewski, R. \& Pielowski, Z., 1956: Metoda badań ekologicznych nad drobnymi gryzoniami w warunkach leśnych w oparciu o wykorzystanie przynęty, znakowanie i wypuszczanie złowionych zwierząt. Ekol. pol., B 2, 3: 209-214, Warszawa.

2. Andrzejewski, R. \& Wierzbowska, T., 1960: On the degree of residency and migrancy in populations of small rodents. Bull. Acad. Pol. Sci., Cl. II, 8, 7: 293-300, Warszawa.

-3. Andrzejewski, R. \& W i erzbowska, T., 1961: An attempt at assessing the duration of residence of small rodents in a defined forest area and the rate of interchange between individuals. Acta theriol., 5, 12: 153-172, Białowieża.

4. Andrzejewski, R. \& Wroclawek, H., 1961: Mass occurrence of Apodemus agrarius ( $\mathrm{P}$ allas 1771 ) and variations in the number of associated $\mathrm{Mu}$ ridae. Acta theriol., 5, 13: 173-184, Białowieża.

5. Borowski, S. \& Dehne1, A., 1952: Materiały do biologii Soricidae. Ann. Univ. M. Curie-Skłodowska, C 7, 6: 305-448, Lublin.

6. Calhoun, J. \& We b b, W., 1953: Induced emigrations among small mammals. Science, 117, 3040: 358-360, Washington.

7. Hayne, W., 1949: Calculation of size of home range. J. Mammal., 30, 1, Lawrence.

8. (N a u mov) Н а умов, Н. П., 1955: Экология животных. Москва.

9. (N a u mov) Н а у мов, Н. П., 1948: Очерки сравнительной экологии мышевидных грызунов. Советская Наука: 1-204. Москва-Леиниград.

10. Petrusewicz, K. \& Andrzejewski, R., 1962: Natural history of a free-living population within the population. Ekol. pol. A.

Polish Academy of Sciences,

Institute of Ecology,

Warsaw, Nowy Swiat 72 .

\section{STRESZCZENIE}

Celem pracy jest próba ustalenia sposobu likwidacji przez gryzonie luki wytworzonej w ich zasiedleniu. Lukę wytwarzano eksperymentalnie odławiając zwierzęta $\mathrm{z}$ określonej powierzchni w lesie.

Badania prowadzono na terenie Kampinoskiego Parku Narodowego w lasach przy Stacji Terenowej Zakładu Ekologii P.A.N. w Dziekanowie Leśnym.

$\mathrm{Na}$ badanych terenach występują licznie trzy gatunki gryzoni: Clethrionomys giareolus ( $\mathrm{Schreber} 1780$ ), Apodemus agrarius ( $\mathrm{Pa} 11$ as 1771) i Apodemus flavicollis (M e l c h i or 1834).

Metoda badań polega na połowach gryzoni (Tabela 4) w pułapki żywolowne, znakowaniu indywidualnym i wypuszczaniu. Lukę wytwarzano przez codzienny odłów w ciągu kilku do kilkunastu dni. Wyniki połowów zestawiono według metody „kalendarza złowień". Zastosowana metoda połowów i zestawienia danych pozwala na:

1. Wysoce dokładne (jak na badania terenowe) poznanie składu i liczebności populacji

2. poznanie historii życia na badanej powierzchni każdego osobnika osiedlonego

3. odłowienie w około $95 \%$ myszy osiedlonych na powierzchni badań (Tabele 2,3 ). 
Wykonano 9 eksperymentów. W eksperymentach 1-8 badania prowadzono na powierzchni eksperymentalnej (na której przeprowadzano odłowy) oraz na graniczącej z nią powierzchni kontrolnej (Tabela 1, fig. 1). W eksperymencie dziewiątym istniała tylko powierzchnia eksperymentalna.

Podstawowy schemat wszystkich eksperymentów był podobny i dzielił się na trzy etapy (fig. 2):

1. ustalanie składu ilościowego i rozmieszczenia zwierząt na badanej powierzchni

2. przeprowadzenie odłowu na powierzchni eksperymentalnej - zabranie wszystkich złowionych zwierząt

3. śledzenie procesu wypełniania się wytworzonej luki czyli nachodzenia i osiedlania się nowych myszy.

Przeprowadzone obserwacje wykazaly:

Proces wypełniania luki odbywa się kosztem części migrującej populacji a nie kosztem zwierząt osiedlonych na peryferiach terenu odłowionego (Tabela 5).

„Regeneracja” odbywa się przez zmniejszenie tempa ubywania czyli przedłużenie czasu przebywania imigrantów na powierzchni odłowionej (Tabele 8-9).

Tempo „regeneracji” wytworzonej eksperymentalnie luki w populacjach gryzoni zależy od ogólnego stanu populacji otaczającej teren odłowiony. Ogólnie biorąc po 2-4 tygodniach poziom ilościowy osiadłych gryzoni wyrównuje się i nie wykazuje wpływu poprzedniego odłowu.

Nie stwierdzono zwiększonego nachođzenia i osiedlania się myszy na odłowionej powierzchni $\mathrm{w}$ porównaniu z powierzchnią kontrolną nie odłowioną (Tabele $6,7,8$ ). 